\title{
ROOT AND SHOOT GROWTH OF SOYBEAN (GLYCINE MAX) AS INFLUENCED BY NATUALLY AVAILABLE PHOSPHOUS NUTRITION WITH MANURE
}

\author{
Piraveena Sithamparam ${ }^{1}$ and Thayamini H. Seran ${ }^{1}$
}

\begin{abstract}
Effect of rock phosphate (RP) combined with cattle manure (CM) on plant growth of soybean was studied. As basal fertilizer application, $R P$ at different levels $(0,25,50,75$ and $100 \mathrm{~kg} / \mathrm{ha}$ ) along with 10 tons/ha CM (T2-T6) were applied and also recommended chemical fertilizer ( $T 1$ as a control). The results revealed that seed-pod ratio ranged from 0.68 to 0.74 at the maturity stage (12 weeks) and the highest ratio (0.74) was reported in RP (50 kg/ha) with CM (T4) and lowest value (0.68) was observed when CM solely applied. Further, the plants grown in inorganic fertilizer had a high root-shoot ratio (1:17) while comparatively lower ratios $(1: 12$ to $1: 15)$ were noted in plants grown with $R P(0-100$ $\mathrm{kg} / \mathrm{ha}$ ) and CM. Application of CM alone or in combination with RP at the optimal level could improve root and shoot growth for better yield of the soybean with less environmental pollution.
\end{abstract}

Key words: Cattle manure, dry matter yield, rock phosphate, root-shoot ratio, soybean

\section{INTRODUTION}

Soybean (Glycine max) is an important pulse crop and a high nutritive crop. It consists of $36.5 \%$ protein, $30.2 \%$ carbohydrate and $19.9 \%$ fat in $100 \mathrm{~g}$ as well as $5 \%$ of lycine that is deficient in most of the cereals (Purseglove, 1996). Farmers believe that legume does not require external inputs therefore they do not apply for legume production (Kan'ankuk'a 1999). On the other hand, the excessive vegetative growth of legume plants developed in fertile soils may lead to reduce grain yield (Rutunga and Neel, 2006). Soybean being a leguminous crop has ability to fix atmospheric nitrogen into available form that is easily absorbed by plants, however, soybean needs starter dosage of nitrogen during early stage. In addition, phosphorus is an important in nodule formation. Hence, it is provided by the locally available organic sources at low cost.

With increasing population, both organic and inorganic fertilizers are required to improve production of most crops. Organic sources enhance the macro and micronutrient contents of the soil, soil water holding capacity, $\mathrm{pH}$ and soil structure (Lekasi et al., 2001). Plant grown with organic manure is less susceptible to insects than plants grown with inorganic fertilizer (Lotter, 2003). Organic matter plays an important role in the chemical behaviour of several metals in soils (Abou El-Magd et al., 2006) and also helps to produce well drained and aerated soil. Moreover, application of organic manure has more beneficial residual effect than inorganic fertilizers which does not last beyond one season (Rutunga and Neel, 2006).

Department of Crop Science, Faculty of Agriculture, Eastern University, Chenkalady, Sri Lanka, email: thayaseran@yahoo.com, phone 94652240760 
Naturally available rock phosphate and locally available organic manures in Sri Lanka can be used as fertilizers with low cost and less environmental hazards than synthetic fertilizers. Rock phosphate (RP) can supply phosphorus (P) at lower cost than other usually used commercial fertilizers (Dev et al., 1997). However, very little eppawela rock phosphate is currently used in agriculture (George et al., 2002). Cattle manure has most of the macro and micro nutrients required for plant growth and development hence it can be used without environmental pollution and health hazard however it is release P slowly among other macronutrients.

\section{OBJECTIVES}

The objective of this experiment was designed to study the response of rock phosphate and cattle manure on plant performance of soybean on sandy regosol in eastern region of Sri Lanka.

\section{MATERIALS AND METHODS}

A field experiment was conducted in 2010/2011 to assess the effect of rock phosphate and cattle manure on plant performance of soybean in the Eastern region of Sri Lanka which is located at the latitude of $7^{\circ} 43^{\prime}$ and longitude of $81^{\circ} 42^{\prime}$. It comes under the low country dry zone and soil type is sandy regosol. During growing season, an average rainfall ranged from 67 to $350 \mathrm{~mm}$ while minimum and maximum mean temperatures were $24^{\circ} \mathrm{C}$ and $32^{\circ} \mathrm{C}$ respectively.

\section{EXPERIMENTAL DESIGN}

The experiment was designed in a Randomized Complete Block Design and there were six treatments with four replications. The treatments included as follows:

T1: Recommended chemical fertilizer application @ $23 \mathrm{~N}: 67.5 \mathrm{P}_{2} \mathrm{O}_{5}: 45 \mathrm{~K}_{2} \mathrm{O} \mathrm{kg} / \mathrm{ha}$ as basal and $23 \mathrm{~N} \mathrm{~kg} / \mathrm{ha}$ top dressing

T2: $0 \mathrm{~kg} / \mathrm{ha}$ rock phosphate +10 tons $/ \mathrm{ha}$ cattle manure

T3: $25 \mathrm{~kg} / \mathrm{ha}$ rock phosphate +10 tons $/$ ha cattle manure

T4: $50 \mathrm{~kg} / \mathrm{ha}$ rock phosphate +10 tons $/$ ha cattle manure

T5: $75 \mathrm{~kg} / \mathrm{ha}$ rock phosphate +10 tons $/$ ha cattle manure

T6: $100 \mathrm{~kg} / \mathrm{ha}$ rock phosphate +10 tons $/$ ha cattle manure

\section{AGRONOMIC PRACTICES}

The land was ploughed, leveled and subsequently seeds of soybean cv PB1 were sown at $3 \mathrm{~cm}$ depth in September. Plot size was $1.44 \mathrm{~m}^{2}$. One plant per hill was maintained with a spacing of $40 \mathrm{~cm}$ between rows and $7 \mathrm{~cm}$ within rows. As basal application of fertilizers, eppawela rock phosphate $(0-100 \mathrm{~kg} / \mathrm{ha})$ with cattle manure (10 tons/ha) were applied two weeks before planting to the experimental plots (T2-T6) except control treatment (T1) where recommended chemical fertilizers $(50 \mathrm{~kg} / \mathrm{ha}$ urea, $150 \mathrm{~kg} / \mathrm{ha}$ triple super phosphate and $75 \mathrm{~kg} / \mathrm{ha}$ muriate of potash) were applied two days before planting. Four weeks after planting, 50 $\mathrm{kg} / \mathrm{ha}$ urea was applied as top dressing to all the experimental plots. Cattle manure contains $1.08 \% \mathrm{~N}, 0.12 \% \mathrm{P}_{2} \mathrm{O}_{5}$ and $0.76 \% \mathrm{~K}_{2} \mathrm{O}$ meanwhile $\mathrm{P}_{2} \mathrm{O}_{5}$ in rock phosphate is $32 \%$. All other agronomic practices were carried out as recommended. 


\section{AGRONOMIC PARAMETERS}

Plants were uprooted every two weeks interval in each treatment and agronomic parameters were measured. Leaf area was taken by using Leaf area meter. Fresh and oven dried weights of leaves, shoot, root and pods per plant were recorded by electric balance. Root-shoot ratios were calculated on dry weight basis.

STATISTICAL ANALYSIS

All the collected data during the experiment were analyzed with the statistical package of SAS. The means of different treatments were compared by using Tukey's Studentized Range (HSD) Test at $\mathrm{P}=0.05$.

\section{RESULTS AND DISCUSSIONS}

\section{LEAF AREA}

Remarkable variations were noted in the leaf area of soybean plant by phosphate application (Table 1). At the $2^{\text {nd }}$ week and after $6^{\text {th }}$ week of planting, leaf area showed significant differences $(P<0.05)$ among the treatments and it ranged from $38.52 \mathrm{~cm}^{2}$ (T2) to $47.11 \mathrm{~cm}^{2}$ (T6) at the $2^{\text {nd }}$ week and $876.18 \mathrm{~cm}^{2}$ (T2) to 935.15 $\mathrm{cm}^{2}$ (T6) at the $12^{\text {th }}$ week. The lowest value of leaf area was recorded when applied cattle manure solely (T2) may be due to low availability of phosphorus to the plant. Further it was found that at the $12^{\text {th }}$ week, control treatment (T1) gave lower values $\left(917.50 \mathrm{~cm}^{2}\right)$ of leaf area than the combined application (T3-T6) of rock phosphate (RP) and cattle manure (CM) (leaf area 919.50-935.15 $\mathrm{cm}^{2}$ ). Combined usage of fertilizers supply both micro and micro nutrients to the plant for the development of leaves.

Table 1. Effect of different levels of rock phosphate with cattle manure on leaf area/plant.

\begin{tabular}{lcccccc}
\multicolumn{7}{c}{ Leaf area $\left(\mathrm{cm}^{2}\right)$ per plant at various growing periods } \\
Treatments & $2^{\text {nd }}$ week & $4^{\text {th }}$ week & $6^{\text {th }}$ week & $8^{\text {th }}$ week & $10^{\text {th }}$ week & $12^{\text {th }}$ week \\
$\mathrm{T}_{1}$ (control) & $41.35 \mathrm{ab}$ & 83.51 & 352.53 & $988.40 \mathrm{ab}$ & $1546.25 \mathrm{ab}$ & $917.50 \mathrm{a}$ \\
$\mathrm{T}_{2}$ & $38.52 \mathrm{~b}$ & 84.36 & 347.87 & $917.25 \mathrm{bc}$ & $1465.90 \mathrm{~b}$ & $876.18 \mathrm{~b}$ \\
$\mathrm{~T}_{3}$ & $44.52 \mathrm{ab}$ & 84.74 & 374.79 & $998.00 \mathrm{ab}$ & $1560.75 \mathrm{ab}$ & $919.50 \mathrm{a}$ \\
$\mathrm{T}_{4}$ & $44.29 \mathrm{ab}$ & 84.43 & 376.77 & $1055.00 \mathrm{ab}$ & $1575.00 \mathrm{ab}$ & $933.80 \mathrm{a}$ \\
$\mathrm{T}_{5}$ & $45.18 \mathrm{a}$ & 84.54 & 411.88 & $1049.53 \mathrm{ab}$ & $1612.25 \mathrm{ab}$ & $934.67 \mathrm{a}$ \\
$\mathrm{T}_{6}$ & $47.11 \mathrm{a}$ & 85.79 & 412.90 & $1067.15 \mathrm{a}$ & $1631.75 \mathrm{a}$ & $935.15 \mathrm{a}$ \\
$\mathrm{F}$ test & $*$ & $\mathrm{~ns}$ & $\mathrm{~ns}$ & $*$ & $*$ & $*$ \\
\hline
\end{tabular}

*- $\mathrm{P}<0.05$ according to $\mathrm{F}$ test. Means with the same letter in each column are not significantly different using Tukey's Studentized Range (HSD) Test at 5\% level.

At the various growing periods, there was increasing trend of leaf area with increasing rate of RP in combination with $C M$ application $\left(2^{\text {nd }}-12^{\text {th }}\right.$ weeks $)$ and phosphate application slightly increased the leaf area as reported by Magani and Kuchinda (2009) in cowpea. The development of trifoliate leaves increase with phosphate application (Cassman et al., 1980) and phosphate stimulates symbiotic $\mathrm{N}_{2}$ fixation resulting in luxuriant vegetative growth (Setiyo et al., 2004). Leaf area reached maximum $\left(1465.90-1631.75 \mathrm{~cm}^{2}\right)$ during pod filling stage $\left(10^{\text {th }}\right.$ week) and 
declined $\left(876.18-935.15 \mathrm{~cm}^{2}\right)$ during late reproductive stage $\left(12^{\text {th }}\right.$ week) because of the falling of leaves.

\section{LEAF WEIGHT}

The effects of different levels of phosphate application with cattle manure in the dry weights of leaves are shown in Table 2 . Among the treatments, RP at $50 \mathrm{~kg} / \mathrm{ha}$ with CM (T4) exhibited the highest leaf weights at all growing periods $\left(2^{\text {nd }}-12^{\text {th }}\right.$ weeks). The remarkable differences $(P<0.05)$ were observed in the dry weights of leaves among the treatments until $8^{\text {th }}$ week. At the beginning of the vegetative growth $\left(2^{\text {nd }}\right.$ week), the dry weights of leaves were within the range of $0.04 \mathrm{~g}$ to $0.05 \mathrm{~g}$. It was increased progressively until pod filling stage. At the later stage of growing $\left(12^{\text {th }}\right.$ week), T4 had greater dry weight $(4.66 \mathrm{~g})$ of leaves than other treatments and lower dry weight $(3.99 \mathrm{~g})$ was observed in T1. In addition, leaf weight was increased with the increasing rate $(0-50 \mathrm{~kg} / \mathrm{ha})$ of phosphate application. Similar observation was responded by Cassman et al., (1981) found the highest dry matter yield at the optimum level of phosphate application which is an important to enhance dry matter production of soybean plant (Freire, 1977).

\section{STEM WEIGHT}

The responses to the combined application of rock phosphate with cattle manure in stem dry weights are presented in Table 2 . No significant differences $(P>0.05)$ were observed at the early stages however there were remarkable variations $(P<0.05)$ noted in the dry weights of shoots after $6^{\text {th }}$ weeks. It was further observed that dry weights $(1.31 \mathrm{~g}-1.64 \mathrm{~g})$ were increased with the increasing levels $(0-100 \mathrm{~kg} / \mathrm{ha})$ of phosphate respectively at the $12^{\text {th }}$ week. A similar trend was seen in leaf area parameter also. Shoot growth was affected by P supply as indicated by Cassman et al. (1980). Thus several researchers (Setiyo et al., (2004; Cadish et al., 1993; Kumaraswamy et al., 2007; Nwoke et al., 2009) mentioned shoot weight increased with the phosphate application.

\section{ROOT WEIGHT}

The dry weights of roots were not significantly $(P>0.05)$ different at all growing stages as shown in Table 2. Cattle manure application (T2-T6) gave a greater root weights after vegetative stage than the control. Generally organic manure improves soil physical and chemical properties for better root growth. In addition, Phosphorus application gave better root system (Setiyo et al., 2004) that is a good weights of indication of subsequent plant performance. Among the treatments, the dry weight of roots was higher in the combined application of RP $(50 \mathrm{~kg} / \mathrm{ha})$ after $6^{\text {th }}$ week and the dry root weight was $1.72 \mathrm{~g}$ at the $10^{\text {th }}$ week and $1.33 \mathrm{~g}$ at the $12^{\text {th }}$ week. At the later growing stage after $10^{\text {th }}$ week, control treatment showed the lowest value of root weight than other treatments, it may be due to the release of micronutrient and phosphorus from RP and CM continuously. 
Table 2. Effect of different levels of rock phosphate with cattle manure on dry leaves, stem and root of plant.

\begin{tabular}{|c|c|c|c|c|c|}
\hline \multirow[b]{3}{*}{ Treatments } & \multicolumn{5}{|c|}{ Dry weight (g) of plant parts at various growing periods } \\
\hline & \multicolumn{2}{|c|}{ Vegetative growth } & \multirow{2}{*}{$\begin{array}{l}\frac{\text { Flowering }}{6^{\text {th }} \text { week }} \\
\end{array}$} & \multirow{2}{*}{$\begin{array}{l}\text { Pod formation } \\
8^{\text {th }} \text { week }\end{array}$} & \multirow{2}{*}{$\begin{array}{l}\text { Maturity } \\
12^{\text {th }} \text { week }\end{array}$} \\
\hline & $2^{\text {nd }}$ week & $4^{\text {th }}$ week & & & \\
\hline \multicolumn{6}{|c|}{ Leaves } \\
\hline $\mathrm{T}_{1}$ (Control) & $0.05 \mathrm{a}$ & $0.33 \mathrm{a}$ & $1.56 \mathrm{~b}$ & $3.97 \mathrm{~b}$ & 3.99 \\
\hline $\mathrm{T}_{2}$ & $0.04 \mathrm{~b}$ & $0.30 \mathrm{~b}$ & $1.56 \mathrm{~b}$ & $4.16 \mathrm{ab}$ & 4.10 \\
\hline $\mathrm{T}_{3}$ & $0.04 \mathrm{~b}$ & $0.29 \mathrm{c}$ & $1.56 \mathrm{bc}$ & $4.03 \mathrm{ab}$ & 4.15 \\
\hline $\mathrm{T}_{4}$ & $0.05 \mathrm{a}$ & $0.33 \mathrm{a}$ & $1.61 \mathrm{a}$ & $4.52 \mathrm{a}$ & 4.66 \\
\hline$T_{5}$ & $0.04 \mathrm{~b}$ & $0.26 \mathrm{c}$ & $1.48 \mathrm{~b}$ & 4.10ab & 4.13 \\
\hline $\begin{array}{l}\mathrm{T}_{6} \\
\mathrm{~F} \text { test }\end{array}$ & $\underset{*}{0.04 b}$ & $\underset{*}{0.23 \mathrm{C}}$ & ${ }_{*}^{1.41 \mathrm{C}}$ & $\underset{*}{4.04} \mathrm{ab}$ & $\begin{array}{l}4.11 \\
\mathrm{~ns}\end{array}$ \\
\hline \multicolumn{6}{|c|}{$\underline{\text { Stem }}$} \\
\hline $\mathrm{T}_{1}$ (Control) & 0.06 & 0.14 & 0.69 & $1.61 \mathrm{a}$ & $1.89 \mathrm{a}$ \\
\hline $\mathrm{T}_{2}$ & 0.04 & 0.12 & 0.58 & $1.31 \mathrm{~b}$ & $1.31 \mathrm{~b}$ \\
\hline $\mathrm{T}_{3}$ & 0.04 & 0.14 & 0.59 & $1.41 \mathrm{ab}$ & $1.41 \mathrm{~b}$ \\
\hline $\mathrm{T}_{4}$ & 0.04 & 0.16 & 0.56 & $1.47 \mathrm{ab}$ & $1.43 \mathrm{~b}$ \\
\hline$T_{5}$ & 0.05 & 0.16 & 0.61 & $1.33 \mathrm{~b}$ & $1.46 \mathrm{~b}$ \\
\hline & 0.04 & 0.16 & 0.61 & $1.35 \mathrm{~b}$ & $1.64 \mathrm{ab}$ \\
\hline$F$ test & ns & ns & ns & * & * \\
\hline \multicolumn{6}{|c|}{$\underline{\text { Root }}$} \\
\hline $\mathrm{T}_{1}$ (Control) & 0.06 & 0.12 & 0.53 & 1.14 & 1.03 \\
\hline $\mathrm{T}_{2}$ & 0.05 & 0.11 & 0.52 & 1.06 & 1.25 \\
\hline$T_{3}$ & 0.05 & 0.11 & 0.54 & 1.06 & 1.27 \\
\hline $\mathrm{T}_{4}$ & 0.05 & 0.11 & 0.54 & 1.17 & 1.33 \\
\hline $\mathrm{T}_{5}$ & 0.05 & 0.11 & 0.51 & 1.04 & 1.26 \\
\hline $\mathrm{T}_{6}$ & 0.05 & 0.11 & 0.49 & 1.05 & 1.17 \\
\hline
\end{tabular}

*- $\mathrm{P}<0.05$ according to $\mathrm{F}$ test. Means with the same letter in each column are not significantly different using Tukey's Studentized Range (HSD) Test at $5 \%$ level.

\section{NUMBER OF NODULES}

Significant effect $(P<0.05)$ was found in the number of nodules per plant by the application of different levels of rock phosphate (RP) with cattle manure (CM) after six weeks of planting (Table 3$)$. There was remarkable variation $(P>0.05)$ observed in the nodule formation between control treatment and different levels of RP with CM application at the different growing stages. Phosphorus had remarkable effect on the number of nodules per plant with the highest values recorded when applied $100 \mathrm{~kg} / \mathrm{ha}$ RP with CM. Setiyo et al. (2004) stated that the number of nodule initiation in soybean was increased significantly by the addition of phosphate and phosphorus $(P)$ is an essential for the development and function of the formed nodules.

\section{NUMBER OF PODS}

The effect of phosphate application influenced on the formation of pods (Table 3) and it was resulted a remarkable variation $(\mathrm{P}<0.05)$ after $8^{\text {th }}$ week onwards. Rock 
phosphate at the rate of $50 \mathrm{~kg} / \mathrm{ha}$ with cattle manure exhibited the highest value of pod number per plant. Phosphorus is a vital element for pod formation and their development (Griffith, 2010) and its application increased the number of pods however applied phosphate in excess did not increase soybean yield (Jones et al., 1997). There was a highest number of pods was observed when applied 50 $\mathrm{kg} / \mathrm{ha}$ rock phosphate with cattle manure.

Table 3. Effect of different levels of rock phosphate with cattle manure on the number of nodules and pods per plant.

\begin{tabular}{|c|c|c|c|c|c|c|}
\hline \multirow[b]{2}{*}{ Treatments } & \multicolumn{3}{|c|}{ Number of nodules } & \multicolumn{2}{|c|}{ Number of pods } & \multirow[b]{2}{*}{$12^{\text {th }}$ week } \\
\hline & $6^{\text {th }}$ week & $8^{\text {th }}$ week & $10^{\text {th }}$ week & $8^{\text {th }}$ week & $10^{\text {th }}$ week & \\
\hline $\mathrm{T}_{1}$ & 3.50 & $13.25 \mathrm{c}$ & $24.50 \mathrm{c}$ & 20.00 & $39.00 \mathrm{ab}$ & $39.20 \mathrm{~b}$ \\
\hline $\mathrm{T}_{2}$ & 4.00 & $22.00 \mathrm{~b}$ & $27.00 \mathrm{~b}$ & 19.50 & $38.75 \mathrm{~b}$ & $38.72 \mathrm{c}$ \\
\hline $\mathrm{T}_{3}$ & 4.25 & $22.00 \mathrm{~b}$ & $27.25 \mathrm{~b}$ & 20.71 & $39.25 \mathrm{ab}$ & $39.05 \mathrm{bc}$ \\
\hline $\mathrm{T}_{4}$ & 4.00 & $24.25 b$ & $27.50 \mathrm{~b}$ & 25.02 & $40.25 \mathrm{a}$ & $40.02 \mathrm{a}$ \\
\hline$T_{5}$ & 3.25 & $28.25 a b$ & $28.00 \mathrm{~b}$ & 21.71 & $39.00 a b$ & $39.56 \mathrm{ab}$ \\
\hline $\mathrm{T}_{6}$ & 3.25 & $32.50 \mathrm{a}$ & $33.00 \mathrm{a}$ & 20.05 & $39.25 \mathrm{ab}$ & $39.02 \mathrm{~b}$ \\
\hline F test & ns & $*$ & $*$ & ns & * & * \\
\hline
\end{tabular}

Means with the same letter in each column are not significantly different using Tukey's Studentized Range (HSD) Test at 5\% level. F test: ns - P>0.05, ${ }^{*}-\mathrm{P}<0.05,{ }^{* *}-\mathrm{P}<0.01$.

\section{POD AND SEED WEIGHTS}

The effect of the rock phosphate in combination with cattle manure on pod weight of soybean is clearly shown in Table 4. There were no remarkable variations $(P>0.05)$ were noted in the dry weight of pods except at the $12^{\text {th }}$ week. Of the six treatments studied, RP at the rate of $50 \mathrm{~kg} / \mathrm{ha}$ with CM (T4) exhibited the highest dry weight of pods at different growing stages. At the $12^{\text {th }}$ week, dry weight of pods per plant in T4 was $12.08 \mathrm{~g}$ whereas $11.28 \mathrm{~g}$ in T1. The lowest dry weights of pods per plant were observed at the different stages when applied cattle manure solely and weight was $10.28 \mathrm{~g}$ at the $12^{\text {th }}$ week. It may be due to the slow release of Phosphorus from cattle manure. Phosphorus is a vital element for pod formation and its development (Griffith, 2010) and its demand is greatest at pod and seed development (Usherwood, 1998). The $50 \mathrm{~kg} / \mathrm{ha}$ of RP application increased the dry weights of pods and seeds in the present study (Table 4; Figure 1 and 2). However, applied phosphate in excess did not increase soybean yield as reported by Jones (Jones et al., 1997). The seed-pod ratio is the ratio of the weight of the seeds to the weight of the pods of a plant. It ranged from 0.68 to 0.74 and the highest ratio $(0.74)$ was reported in T4 and lowest value $(0.68)$ was observed when cattle manure only applied. 
Table 4. Effect of different levels of rock phosphate with cattle manure on dry weight of pods per plant.

\begin{tabular}{llcc}
\hline & \multicolumn{2}{c}{ Pod weight per plant at various growing periods } \\
\cline { 2 - 4 } Treatments & $8^{\text {th }}$ week & $10^{\text {th }}$ week & $12^{\text {th }}$ week \\
\hline $\mathrm{T}_{1}$ (Control) & $1.30 \pm 0.04$ & $9.13 \pm 0.52$ & $11.28 \pm 0.44 \mathrm{ab}$ \\
$\mathrm{T}_{2}$ & $1.03 \pm 0.03$ & $8.86 \pm 0.35$ & $10.28 \pm 0.50 \mathrm{~b}$ \\
$\mathrm{~T}_{3}$ & $1.04 \pm 0.16$ & $8.92 \pm 0.29$ & $10.66 \pm 0.58 \mathrm{~b}$ \\
$\mathrm{~T}_{4}$ & $1.37 \pm 0.18$ & $9.17 \pm 0.33$ & $12.08 \pm 0.38 \mathrm{a}$ \\
$\mathrm{T}_{5}$ & $1.05 \pm 0.19$ & $9.03 \pm 0.29$ & $11.69 \pm 0.21 \mathrm{ab}$ \\
$\mathrm{T}_{6}$ & $1.05 \pm 0.05$ & $8.95 \pm 0.29$ & $11.58 \pm 0.14 \mathrm{ab}$ \\
$\mathrm{F}$ test & ns & ns & ${ }^{*}$ \\
\hline
\end{tabular}

.* $\mathrm{P}<0.05$ according to $\mathrm{F}$ test. Means with the same letter in each column are not significantly different using Tukey's Studentized Range (HSD) Test at 5\% level.

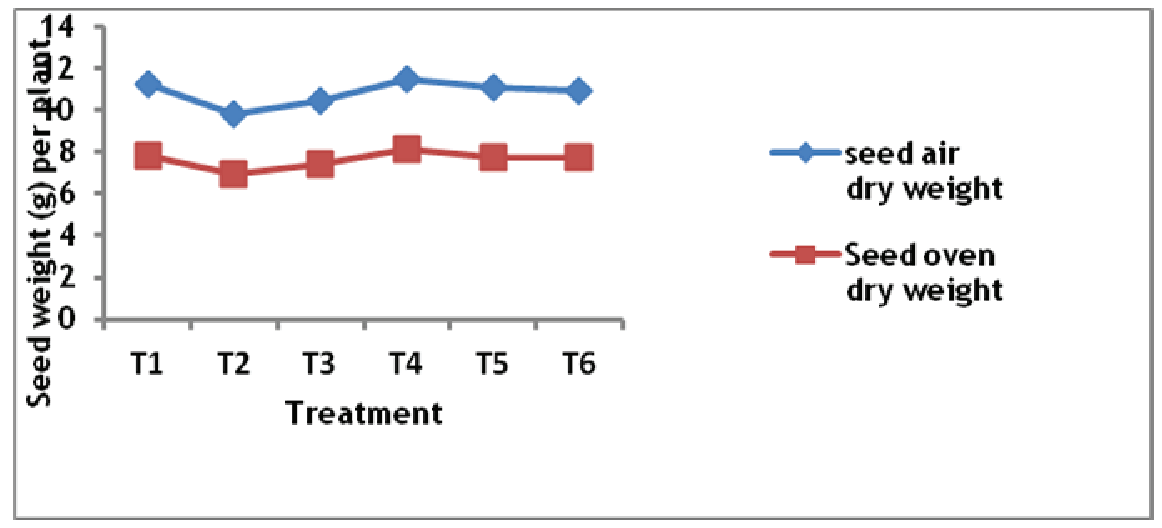

Figure 1. Effect of different levels of rock phosphate with cattle manure on weight of seeds per plant at $12^{\text {th }}$ week

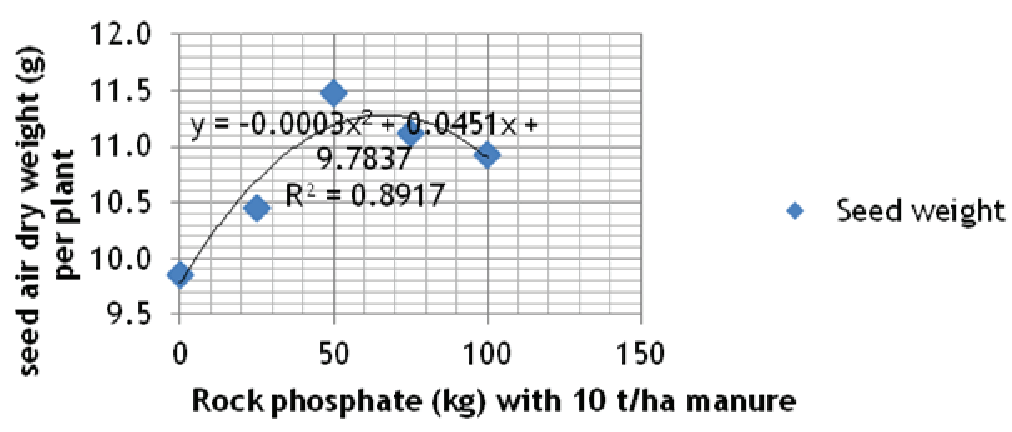

Figure 2. A graphic representation of trend in seed weight per soybean plant as influenced by the different levels of rock phosphate with cattle manure. 


\section{DRY MATTER CONTENT}

The effect of different levels of phosphate on the dry matter yield of soybean plant is presented in Table 5 . The maximum value of dry matter $(0.17 \mathrm{~g})$ was recorded in control treatment $(\mathrm{TI})$ among the tested treatments at the $2^{\text {nd }}$ week and it ranged from 0.13 to $0.17 \mathrm{~g}$. Further, it was noted that it was increased progressively in all treatments. In this experiment, RP at $50 \mathrm{~kg} / \mathrm{ha}$ with CM (T4) resulted in maximum dry matter accumulation of plant after $6^{\text {th }}$ week onward mainly due to increasing leaf and pod weights. At the $12^{\text {th }}$ week, T4 gave the highest dry matter yield (19.5 g per plant) whereas lowest value $(16.94 \mathrm{~g})$ was marked in T2 while T1 produced $18.19 \mathrm{~g}$ dry matter per plant. The results are supported with Freire (1977) who found the highest dry matter yield at the optimum P level in cowpea (Freire, 1977) and P deficiency affected the whole plant fresh and dry mass (Tsvetkova and Georgiev, 2003).

Table 5. Effect of different levels of rock phosphate with cattle manure on the dry matter content of plant.

\begin{tabular}{lcccccc}
\hline & \multicolumn{6}{c}{ Plant dry matter $(\mathrm{g})$ at various growing periods } \\
\cline { 2 - 7 } Treatments & $2^{\text {nd }}$ week & $4^{\text {th }}$ week & $6^{\text {th }}$ week & $8^{\text {th }}$ week & $10^{\text {th }}$ week & $12^{\text {th }}$ week \\
\hline T1 & $0.17 \mathrm{a}$ & 0.59 & 2.78 & $8.02 \mathrm{ab}$ & 17.39 & $18.19 \mathrm{ab}$ \\
T2 & $0.13 \mathrm{~b}$ & 0.53 & 2.66 & $7.56 \mathrm{~b}$ & 17.05 & $16.94 \mathrm{~b}$ \\
T3 & $0.13 \mathrm{~b}$ & 0.54 & 2.69 & $7.54 \mathrm{~b}$ & 17.13 & $17.49 \mathrm{ab}$ \\
T4 & $0.14 \mathrm{~b}$ & 0.60 & 2.71 & $8.53 \mathrm{a}$ & 17.56 & $19.50 \mathrm{a}$ \\
T5 & $0.14 \mathrm{~b}$ & 0.53 & 2.60 & $7.52 \mathrm{~b}$ & 17.34 & $18.54 \mathrm{a}$ \\
T6 & $0.13 \mathrm{~b}$ & 0.50 & 2.51 & $7.49 \mathrm{~b}$ & 17.24 & $18.50 \mathrm{a}$ \\
F test & $*$ & ns & ns & $*$ & $n s$ & $*$ \\
\hline
\end{tabular}

*- $\mathrm{P}<0.05$ according to $\mathrm{F}$ test. Means with the same letter in each column are not significantly different using Tukey's Studentized Range (HSD) Test at 5\% level.

\section{ROOT-SHOOT RATIOS}

Root-shoot ratios help to assess the overall health of plant at each growth stage. The root-shoot ratio ranged from 1.2 at the early stages (2 WAP) of vegetative growth to 1.4 at the flowering stage (6 WAP) i.e. the shoot weight was 2 to 4 times more than the root weight because of the subsequent growth of leaves and stems (Table 6 ). The ratio was $1: 6$ at the stage of pod formation ( 8 WAP) and shoot weights increased continuously than the root weights due to the weights of pods. As a result, root-shoot ratios were affected and the plants grown in inorganic fertilizer had a high ratio (1:17) while a comparatively lower ratio was noted in plants grown with cattle manure and rock phosphate $(0-100 \mathrm{~kg} / \mathrm{ha})$ which were $1: 12$ to $1: 15$ at the maturity stage (12 WAP) and lowest ratio (1:12) was observed when cattle manure was added alone. Nitrogen and phosphorus stimulate both root and shoot growth (Ericsson and Ingestad, 1988). 
Table 6. Effect of rock phosphate with cattle manure on root-shoot ratio of soybean plant

\begin{tabular}{lllllll}
\hline & \multicolumn{7}{c}{ Root: shoot ratio of soybean plant } \\
Treatments & $2^{\text {th }}$ week & $4^{\text {th }}$ week & $6^{\text {th }}$ week & $8^{\text {th }}$ week & $10^{\text {th }}$ week & $12^{\text {th }}$ week \\
\hline $\mathrm{T}_{1}$ & $1: 1.8$ & $1: 3.9$ & $1: 4.2$ & $1: 6.0$ & $1: 9.9$ & $1: 16.7$ \\
$\mathrm{~T}_{2}$ & $1: 1.6$ & $1: 3.8$ & $1: 4.1$ & $1: 6.1$ & $1: 9.2$ & $1: 12.5$ \\
$\mathrm{~T}_{3}$ & $1: 1.6$ & $1: 3.9$ & $1: 4.1$ & $1: 6.1$ & $1: 9.3$ & $1: 12.6$ \\
$\mathrm{~T}_{4}$ & $1: 1.8$ & $1: 3.9$ & $1: 4.0$ & $1: 6.3$ & $1: 9.2$ & $1: 13.7$ \\
$\mathrm{~T}_{5}$ & $1: 1.8$ & $1: 3.9$ & $1: 4.1$ & $1: 6.2$ & $1: 9.2$ & $1: 13.7$ \\
$\mathrm{~T}_{6}$ & $1: 1.6$ & $1: 3.6$ & $1: 4.1$ & $1: 6.1$ & $1: 9.1$ & $1: 14.8$ \\
\hline
\end{tabular}

\section{CONCLUSIONS}

The combined application of rock phosphate (50 kg/ha) with cattle manure (10 tons/ha) significantly increased the dry matter (biological) yield of soybean in this experiment. Increased application (0-100 kg/ha) of phosphate increased the leaf area among the growth attributes recorded in this study. The optimum rock phosphate with cattle manure exhibited the highest values of dry weights of leaves, roots and pods. This is due to the optimum supply of plant nutrients from rock phosphate and cattle manure for better plant growth and pod yield of soybean on sandy regosol with less environmental impact.

\section{REFERENCES}

Abou El-Magd, M. M., A. M. El-Bassiony and Z. F. Fawzy, 2006. Effect of organic manure with or without chemical fertilizers on growth, yield and quality of some varieties of Broccoli plants. Journal of Applied Science Research 2(10):791-798.

Cadish, G., B. R. Sylvester, B. C. Boller and J. Nosberger, 1993. Effects of Phophorus and Pottassium on N2 fixation (15N- dilution) of field - grown Centrosema acutifolium and C.macrocarpum. Field Crops Research 31(3-4):329-340.

Cassman, K. G., A. S. Whitney and K. R. Stockinger, 1980. Root growth and dry matter distribution of soybean as affected by Phosphorus stress, nodulation and nitrogen source. Crop Science 20: 239-244.

Cassman. K. G., A. S. Whitney and R. L. Fox, 1981. Phosphorus requirements of soybean and cowpea as affected by mode of Nitrogen nutrition. Agronomy Journal 73:17-22.

Dev, G., A. K. Sarkar, P. K. Sharma and S. K. Sahu, 1997. Studies on residual effect of rock phosphates in different crop sequences in acid soils in India. In: Proceedings of 16th World Congress Soil Science, 20-26 August 1998, Montpellir, Finance. Smposium: 13B.

Ericsson, T. and T. Ingestad, 1988. Nutrition and growth of birch seedlings at varied relative phosphorus addition rates. Physiologia Plantarum 72:227-35.

Freire, J. R. J. 1977. Inoculations of soybeans. In: Exploiting the legume-Rhizobium symbiosis in Tropical Agriculture (Eds) J.M.Vincent, A.S. Whitney and J.Bose. pp 335380. Proceedings of a workshop held at University of Hawaii, Honolulu, USA. August 23-28, 1976.

George, T. S., P. J. Gregory, M. Wood, D. Read and R. J. Buresh, 2002. Phosphatase activity and organic acids in the rhizosphere of potential agroforestry species and maize. Soil Biology Biochemistry 34:1487-1494.

Griffith, B. 2010. Efficient fertilizer use-Phosphorus. The efficient fertilizer use manual. www.rainbowplantfood.com/agronomics/efu/environment. Accessed on 10.12.2013.

Jones, G. D., J. A. Lutz and T. J. Smith, 1997. Effect of Phosphorus and Potassium on soybean nodules and seed yield. Agronomy Journal 69(6):1003-1007.

Kan'ankuk'a, C. N. 1999. Effect of Lime, N and P on growth, yield and yield components of cowpea (V. unguiculata (L.) Walp.). Thesis submitted to the Postgraduate School, Ahmadu Bello University, Zaria, Nigeria, 110 pp. 
Kumaraswamy, C. A., B. L. Raghunandan, M. Chandrashekhar and G. P. Brahmaprakash, 2007.Bio-activation of rock phosphate vis-a-vis seed treatment with phosphorus solubilizing microbes (PSM) in enhancing $P$ nutrition in cowpea and ragi.Indian. Journal of Science Technology 3(7):689-692.

Lekasi, J. K., J. C. Tanner, S. K. Kimani and P. J. C. Harris, 2001. Manure management in the Kenya highlands: Practices and potential. 2nd edition. Manure management in the Kenya highlands: Practices and potential. The Henry Doubleday Research Association, Ryton Organic Gardens, UK.

Lotter, D. W. 2003. Organic Agriculture. Journal of Sustainable Agriculture 21:59-128.

Magani, I. E. and Kuchinda, C. 2009. Effect of phosphorus fertilizer on growth, yield and crude protein content of cowpea.(Vigna unguiculata [L.] Walp) in Nigeria. Journal of Applied Bioscience 23:1387-1393.

Nwoke, O. C., J. A. Okogun, N. Sanginga, J. Diels, R. C. Abaidoo and O. Osonubi, 2009. Phosphate rock utilization by soybean genotypes on a low-P savanna soil and the status of soil $P$ fractions after a subsequent maize crop. African Journal of Biotechnology 8 (15):3479-3488.

Purseglove, J. W. 1996. Tropical crops Dicotyledons. Vol 1 \&2 combined, London: Longman group Ltd.

Rutunga, V. and H. Neel, 2006. Yield trends in the long-term crop rotation with organic and inorganic fertilizers on Alfisols in Mata (Rwanda). Biotechnology Agronomy Social Environment 10(3):217-228.

Setiyo, H. W., A. L. Tek, and M. Leendert't, 2004. Effect of Phosphate on nodule primodia of soy bean (Glycin max M.) in acid soils in rhizotron experiments. Indonesia Journal of Agricultural Science 5(2):37-44.

Tsvetkova, G. E. and G. I. Georgiev, 2003. Effect of phosphorus nutrition on the nodulation, nitrogen fixation and nutrient use efficiency of Bradyrhizobium Japonicum - soy bean (Glycin max M.) symbiosis. Belgian Journal of Plant physiology, special Issue:331-335.

Usherwood, N. R. 1998. A Nutrient Management for top profit soybeans. A Regional newsletter published in June 1998 by the Potash and Phosphate Institute, Potash \& Phosphate Institute (PPI) and the Potash \& Phosphate Institute of Canada (PPIC). 